\title{
Analisis Tata Kelola Dan Perencanaan Investasi Teknologi Informasi Dengan Metode Cobit Dan Val It
}

\author{
Yayan Hendrian \\ Teknologi Komputer, Universitas Bina Sarana Informatika \\ e-mail: yayan.yhn@bsi.ac.id
}

\begin{abstract}
Cara Sitasi: Hendrian, Y. (2019). Analisis Tata Kelola Dan Perencanaan Investasi Teknologi Informasi Dengan Metode Cobit Dan Val It. Jurnal Teknik Komputer, 105-112. doi:10.31294/jtk.v4i2

Abstract - IT Governance and the development of appropriate information technology, aligned with business strategy and in accordance with the target is a priority, but often development projects are not expected to match the even, there are many information technology development project failure or canceled in the middle of the road. That's because information technology governance and IT investment planning are not good. It is necessary to analysis IT governenace and planning of IT investment. The selected sample is PT. Candi Malindo Bangkit with five (5) respondents involved. Tools in this study using the COBIT framework for data and opinions about IT governance and Val IT for IT investment planning. The selected domain from the COBIT framework are DS4 (continuous service), DS5 (information system security) and DS11 (data management), and the domain of Val IT are Value Governance (VG), Portfolio Management (PM) and Investment Management (IM). Then based on the analysis can be known maturity level of IT governance and IT investment planning. The analysis shows that the current PT. Candi Malindo Bangkit still at maturity level 1 (one) or at the level of the initial/Adhoc which means IT governance and IT investment planning has been no standardization process, yet organized and implemented based on the needs of a sudden.
\end{abstract}

Keywords: Audit, IT Governance, COBIT, Val IT

\section{PENDAHULUAN}

Pengembangan teknologi yang tepat dan sesuai dengan target merupakan hal yang menjadi prioritas dalam menyelesaikan proyek-proyek yang berhubungan dengan teknologi informasi, tetapi seringkali proyek-proyek pengembangan tersebut tidak sesuai dengan yang diharapkan bahkan banyak pula proyek pengembangan teknologi informasi yang mengalami kegagalan atau dibatalkan di tengah jalan. Hal itu disebabkan karena investasi pengembangan teknologi informasi tidak direncanakan dengan baik. Investasi pengembangan teknologi informasi sulit dinilai dengan hitung-hitungan matematika karena manfaat pengembangan teknologi informasi memiliki dua aspek yang berbeda, yaitu ada manfaat yang tangible dan manfaat intangible.

Selama beberapa tahun terakhir, hasil-hasil survey menunjukkan $20-70 \%$ dari investasi skala besar terbuang atau terjadi pemborosan karena pengelolaan yang salah sehingga tidak menghasilkan nilai investasi yang menguntungkan. Menurut hasil survey Gartner pada tahun 2002 ditemukan sebanyak $20 \%$ biaya terbuang mencapai nilai 600 juta US dollar. Pada tahun 2004, hasil survey IBM menunjukkan bahwa sebanyak 1000 CIO rata-rata kehilangan $40 \%$ dari nilai investasi TI yang tidak kembali ke organisasi. Sedangkan pada tahun 2006, Standish Group menemukan hanya 35\% dari total proyek pengembangan TI yang berhasil, ini berarti ada $65 \%$ proyek pengembangan TI yang gagal (IT Governance Institute, 2005).

Beberapa penelitian yang berupa analisis maupun auditing tentang tata kelola teknologi informasi dan analisis investasi teknologi informasi telah banyak dilakukan. Sebagian dari penelitian tersebut menggunakan framework COBIT sebagai acuan dalam menentukan maturity level tata kelola TI dan sebagian yang lain menggunakan Val IT sebagai framework untuk mengukur tingkat keberhasilan investasi pengembangan TI. Berdasarkan hasil penelusuran penulis, sampai saat ini belum ada penelitian yang menggabungkan kedua framework tersebut. Sedangkan jika ditelaah lebih jauh, pada hakikatnya kedua framework tersebut bisa digunakan secara bersama-sama karena kedua framework tersebut mempunyai keterkaitan dan hubungan yang erat.

(Adikrisna, 2008) dalam tesisnya yang berjudul "Analisis tata kelola teknologi informasi PT. Surveyor Indonesia menggunakan kerangka kerja CobIT (studi kasus : proses DS 13-mengelola operasi)" menggunakan COBIT pada domain Delivery \& Support dan Monitoring sebagai framework untuk menganalisa sampai sejauh mana pengelolaan TI di PT. Surveyor Indonesia dan mengukur tingkat kematangannya. Pengumpulan 
data dilakukan dengan cara memberikan kuesioner kepada Unit Teknologi Informasi. Penelitian dilakukan melalui beberapa tahap yaitu diawali dengan melakukan pengumpulan dokumen mengenai visi, misi, strategi, tujuan, struktur organisasi dan kebijakan pengelolaan TI PT. Surveyor Indonesia. Setelah melakukan pengumpulan dokumen tersebut tahapan selanjutnya adalah melakukan analisis kondisi pengelolaan TI PT. Surveyor Indonesia yang terdiri dari analisis kedudukan fungsi TI, analisis management awareness, analisis kebutuhan pengelolaan TI, dan analisis tingkat kematangan. Tahapan berikutnya adalah melakukan pemberian rekomendasi untuk mengatasi gap kematangan proses TI dan melakukan penyusunan rancangan model pengelolaan TI untuk PT. Surveyor Indonesia.

Sedangkan (Suharsono, 2007) dalam tesisnya yang berjudul "Penggunaan Val IT Framework untuk menilai perencanaan investasi teknologi informasi (Studi kasus: Universitas Sangga Buana YPKP Bandung)" menggunakan Val IT sebagai framework untuk menilai apakah investasi TI yang telah dilakukan memiliki manfaat atau benefit yang sesuai dan mempunyai keselarasan dengan sasaran strategis Universitas Sangga Buana YPKP, analisis keuntungan financial dan nonfinancial, serta analisis resiko. Metode yang digunakan adalah kajian literature, identifikasi masalah, survey, analisis dan menyusun rekomendasi.

Berdasarkan penelitian pustaka tersebut diatas, sampai saat ini penelitian hanya difokuskan pada satu framework saja dan belum ada peneliti yang menggabungkan framework CobIT dengan Val IT. Oleh karena itu, penulis berusaha mengambil tema penelitian yang berbeda, yaitu dengan menggabungkan framework COBIT dan Val IT sebagai alat bantu penelitian. Domain yang penulis pilih adalah Delivery \& Support (DS) yang difokuskan pada DS 4, DS 5 dan DS 11 untuk menilai sudah sampai sejauh mana pengelolaan sistem informasi di perusahaan, khususnya yang berhubungan dengan pengelolaan data, keamanan sistem informasi, dan pelayanan yang berkelanjutan. Kemudian digabungkan dengan Val IT untuk menilai apakah pengembangan sistem informasi yang telah dilakukan sejalan dengan tujuan bisnis perusahaan.

Oleh karena itu, penelitian ini akan membahas dan melaporkan mengenai analisis tata kelola teknologi informasi pada suatu perusahaan swasta multinasional dengan cara melakukan auditing melalui beberapa tahapan, yaitu tahapan menentukan management awareness, kemudian plotting terhadap COBIT 4.1 dan perhitungan maturity level yang ada serta dikombinasikan dengan Val IT untuk menganalisa apakah investasi teknologi informasi tersebut sesuai dengan prosedur dan harapan perusahaan. Val IT menambahkan Cobit dari sisi perspektif bisnis dan finansial sehingga dapat membantu memberikan masukan berdasarkan hasil audit yang telah dilakukan dengan cara analisis sistem informasi dan TI secara langsung pada bagian Teknologi Informasi dan analisis pengembangan TI yang dilakukan perusahaan. Sampel perusahaan yang akan dianalisis adalah PT. Candi Malindo Bangkit.

Teknologi informasi adalah seperangkat alat atau yang membantu Anda bekerja dengan informasi dan melakukan tugas-tugas yang berhubungan dengan pemrosesan informasi (Kadir \& Terra, 2005).

Menurut Jogiyanto dalam (Kadir \& Terra, 2005) informasi adalah data yang diolah menjadi bentuk yang lebih berguna dan lebih berarti bagi yang menerimanya.

Sedangkan teknologi informasi menurut William dalam (Kadir \& Terra, 2005) adalah teknologi yang menggabungkan komputasi dengan jalur komunikasi berkecepatan tinggi yang membawa data, suara, dan video.

Terdapat beberapa alasan mengapa audit teknologi informasi diperlukan antara lain (Manorang, 2012):

a. Kerugian akibat kehilangan data.

b. Kesalahan dalam pengambilan keputusan.

c. Risiko kebocoran data.

d. Penyalahgunaan computer.

e. Kerugian akibat kesalahan proses perhitungan.

f. Tingginya nilai investasi perangkat keras dan perangkat lunak komputer.

g. Ketatnya persaingan antar perusahaan.

\section{A. Control Objectives Information Technology (COBIT)}

COBIT adalah sekumpulan perangkat dan kerangka kerja yang dapat membantu auditor, pengguna dan manajemen untuk menjembatani jarak antara resiko bisnis, kebutuhan kontrol dan masalah-masalah teknis teknologi informasi. COBIT dikembangkan oleh IT Governance Institute (ITGI) yang merupakan bagian dari Informations Systems Audit and Control Association (ISACA).Manfaat yang didapatkan dari implementasi COBIT adalah (Institute, IT Governance): (1) Lebih meluruskan fokus bisnis; (2) Melihat pemahaman manajemen mengenai teknologi informasi; (3) Memperjelas kepemilikan dan tanggung jawab berdasarkan orientasi proses-proses; (4) Penerimaan secara umum melalui pihak ketiga dan pengatur; (5) Berbagi pengetahuan antara semua stakeholder berdasarkan bahasa yang sama; (6) Memenuhi harapan COSO (Committee of Sponsoring Organisations) Internal Control-Integrated Framework untuk alat kontrol teknologi informasi. 
COBIT mendukung tatakelola teknologi informasi melalui kerangka kerja untuk memastikan (Institute, IT Governance) :(1)Teknologi informasi sejalan dengan bisnis; (2)Teknologi informasi memaksimalkan manfaat bisnis; (3) Sumberdaya teknologi informasi digunakan dengan penuh tanggung jawab; (4) Resiko teknologi informasi diatur dan disahkan.

Kerangka kerja COBIT terdiri dari beberapa arahan (guidelines), yaitu ControlObjectives, Audit Guidelines dan Management Guidelines. COBIT didesain terdiri dari 34 control objectives yang menggambarkan proses teknologi informasi yang terdiri dari 4 tujuan pengendalian tingkat tinggi yang tercermin dalam 4 domain (ITGI,2005) yaitu : (1) Plan and Organise (PO); (2) Acquire and Implement (AI); (3) Deliver and Support (DS); (4) Monitor and Evaluate (ME).

\section{Control Objectives}

Ada 34 Control Objectives yang terdapat pada COBIT(IT Governance Institute, 2005):

\section{Plane and Organise (Perencanaan dan} Pengorganisasian)

PO1 : Define a Strategic IT Plan

PO2 : Define the Information Architecture

PO3:Determine Technological Direction

PO4 :Define the IT Processes, Organisation and Relationship

PO5 :Manage the IT Investment

PO6 :Communicate Management Aims and Direction

PO7 :Manage IT Human Resources

PO8 :Manage Quality

PO9 :Assess and Manage IT Risks

PO10 :Manage Projects

\section{Acquire and implement (Akuisisi dan} Implementasi)

AI1 : Identify Automated Solutions

AI2 :Acquire and maintain Application Software

AI3 :Acquire and maintain Technology Infrastucture

AI4 : Enable Operation and Use

AI5 : Procure IT Resources

AI6 : Manage Changes

AI7 :Install and Accredit Solutions and Changes

3. Deliver and support (Penyampaian dan Dukungan)

DS1 :Define and Manage Service Levels

DS2 :Manage Third-party Services

DS3 :Manage Performance and Capacity

DS4 :Ensure Continuous Services

DS5 :Ensure Systems Security

DS6 :Identify and Allocate Costs

DS7 :Educate and Train Users

DS8 :Manage Service Desk and Incidents
DS9 :Manage the Configuration

DS10:Manage Problems

DS11 :Manage Data

DS12 :Manage the Physical Environtment

DS13 :Manage Operations

4. Monitor and evaluate (Pengawasan dan Evaluasi)

ME1:Monitor and Evaluate IT Performance ME2:Monitor and Evaluate Internal Control

ME3:Ensure Compliance With External Requirements

ME4:Provide IT Governance

Dalam penelitian ini, tidak semua control objective dari domain COBIT 4.1 harus diaudit. Proses audit hanya dilakukan pada tujuan control yang dirasa perlu. Berdasarkan hasil diskusi dengan pihak manajemen PT. Candi Malindo Bangkit, maka didapatkan kesimpulan bahwa saat ini manajemen menitik beratkan pada keamanan sistem informasi, pengelolaan data dan pelayanan yang berkelanjutan terhadap karyawan dan seluruh stakeholder yang terlibat. Kriteria yang harus dipenuhi antara lain: (1) Proses yang memiliki ketersediaan rating factor tertinggi; (2) Proses dengan biaya pengerjaan tertinggi; (3) Proses dengan kondisi yang paling kritis; (4) Disesuaikan dengan sarana pendukung. Berdasarkan beberapa kriteria tersebut, high level control objectives yang diambil untuk diaudit pada domainDeliver and Support (DS), yaitu : (1) Ensure Continous Service (DS 4); (2) Ensure Systems Security (DS 5); (3) Manage Data (DS 11).

\section{B. Maturity Level pada COBIT}

Penskalaan yang terdapat di dalam Cobit (Institute, IT Governance) adalah :

1. Level 0 Non Existent : Perusahaan sama sekali tidak perduli terhadap pentingnya teknologi informasi untuk dikelola secara baik oleh manajemen.

2. Level 1 Initial/ad-hoc : Perusahaan secara reaktif melakukan penerapan dan implementasi teknologi informasi sesuai dengan kebutuhan-kebutuhan mendadak yang ada, tanpa didahului dengan perencanaan sebelumnya.

3. Level 2Repeatable but Intuitive : Perusahaan telah memiliki pola yang berulangkali dilakukan dalam melakukan manajemen aktivitas terkait dengan tata kelola teknologi informasi, namun keberadaannya belum terdefinisi secara baik dan formal sehingga masih terjadi ketidakkonsistenan.

4. Level 3 Define Process : Perusahaan telah memiliki prosedur baku formal dan tertulis yang telah disosialkan ke segenap jajaranmanajemen dan karyawan untuk dipatuhi dan dikerjakan dalam aktivitas sehari-hari.

5. Level 4 Manage : Perusahaan telah memiliki sejumlah indikator atau ukuran kuantitatif yang 
dijadikan sebagai sasaran maupun obyektif kinerja setiap penerapan aplikasi teknologi informasi yang ada.

6. Level 5 Optimized :Perusahaan telah mengimplementasikan tata kelola teknologi informasi yang mengacu pada "best practice".

\section{Val IT}

Val IT framework yang disarikan dari(IT Governance Institute, 2008) adalah kerangka kerja organisasi yang komprehensif dan pragmatis yang memungkinkan penilaian terhadap kreasi bisnis dari investasi teknologi informasi. Didesain untuk digunakan bersama-sama dengan COBIT, Val IT mengintegrasikan seperangkat prinsip-prinsip praktis dan membuktikan prinsip-prinsip tata kelola, prosesproses, melatih dan memberikan panduan kepada panitia/pengurus, tim manajemen eksekutif, dan pemimpin-pemimpin perusahaan guna mengoptimalkan realisasi value dari pengembangan teknologi informasi.

Val IT memberikan proses-proses, pedoman dan dukungan praktis untuk membantu para pemimpin perusahaan, manajemen eksekutif dalam memahami dan melaksanakan peran yang sesuai dengan investasi teknologi informasi seperti ditunjukkan pada gambar 1 .

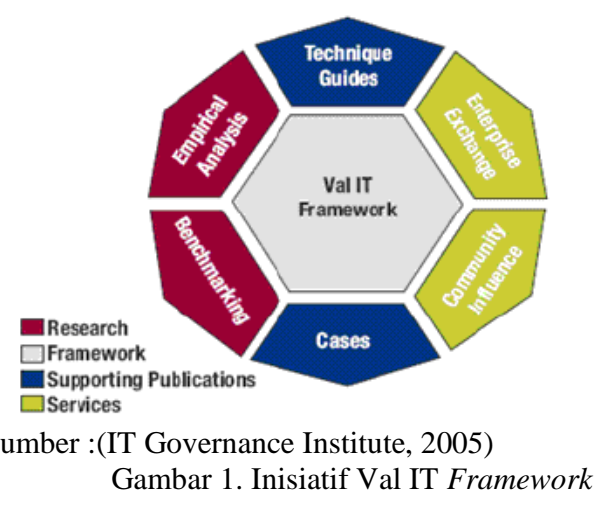

Pada konsep kerja Val IT terdapat beberapa istilah yang berkaitan dengan investasi TI yaitu (Witanti \& Falahah, 2007):

a. Value

Value adalah hasil yang diharapkan diperoleh dari investasi TI yang mendukung bisnis. Hasilnya dapat berupa manfaat financial maupun non finansial.

b. Portfolio

Portfolio adalah kelompok program, proyek, layanan atau asset yang dipilih, dikelola, dan dimonitor untuk mengoptimalisasi pengembalian nilai dari bisnis.

c. Programme

Programme adalah sebuah kelompok terstruktur yang terdiri atas berbagai proyek yang saling terkait, yang semuanya dianggap penting dan diperlukan untuk mencapai sasaran bisnis dan menghasilkan nilai. Proyek ini dapat meliputi, tetapi tidak terbatas pada: perubahan cara bisnis, proses bisnis, pekerjaan yang dilakukan orang, kompetensi yang diperlukan untuk menyelesaikan pekerjaan, teknologi pendukung dan struktur organisasi. Program investasi adalah unit utama investasi dalam Val IT.

d. Project

Project adalah sekumpulan aktivitas yang berfokus utama menghasilkan kemampuan tertentu yang diperlukan untuk mencapai hasil bisnis berdasarkan jadwal dan anggaran yang sudah ditetapkan.

e. Implement

Implement adalah implementasi yang meliputi siklus hidup ekonomis suatu program investasi dari mulai perencanaan hingga investasi tersebut dianggap tidak ada atau tidak lagi digunakan (retirement), yaitu rentang waktu dimana nilai sepenuhnya atas investasi diharapkan dapat/ tidak dapat dicapai.

D. Manfaat Implementasi Val IT

Beberapa manfaat yang dapat diperoleh dari implementasi Val IT adalah sebagai berikut (IT Governance Institute, 2008)

1. Meningkatkan pemahaman dan transparansi atas biaya, resiko, dan manfaat yang dihasilkan dari keputusan manajamen yang dilandasi oleh informasi yang memadai.

2. Meningkatkan kemampuan memilih investasi yang memiliki potensial pengembalian manfaat terbesar.

3. Meningkatkan kecenderungan keberhasilan dalam menjalankan investasi yang dipilihm sehingga investasi tersebut dapat menghasilkan manfaat sesuai yang diharapkan.

4. Mengurangi biaya dengan hanya mengerjakan apa yang seharusnya dikerjakan dan segera mengambil tindakan korektif atau menghentikan investasi yang tidak menghasilkan potensi manfaat yang diharapkan.

5. Mengurangi resiko kegagalan, khususnya kegagalan yang beresiko tinggi.

6. Mengurangi 'kejutan' yang berhubungan dengan biaya dan delivery TI, sehingga dapat meningkatkan nilai bisnis, mengurangi biaya yang tidak perlu dan meningkatkan kepercayaan terhadap IT secara keseluruhan.

\section{E. Prinsip-prinsip Val IT}

Prinsip-prinsip Val IT yang disarikan dari Val IT Framework (IT Governance Institute, 2008) adalah sebagai berikut :

1) Investasi yang dihasilkan dari TI akan dikelola melalui keseluruhan siklus ekonominya.

2) Investasi yang dihasilkan dari TI akan dikelola sebagai sebuah portofolio investasi. 
3) Investasi yang dihasilkan dari TI akan mencakup keseluruhan aktifitas yang diperlukan untuk memperoleh nilai bisnis.

4) Kaidah pemberian nilai akan menunujukkan adanya perbedaan kategori investasi yang akan dievaluasi dan dikelola secara berbeda.

5) Kaidah pemberian nilai akan menjelaskan dan memonitor matrik utama dan akan memberikan respon yang cepat terhadap segala perubahan atau penyimpangan.

6) Kaidah pemberian nilai akan melibatkan seluruh stakeholder dan memberikan akuntabilitas yang tepat bagi penyampaian kapabilitas serta realisasi dari keuntungan bisnis.

7) Kaidah pemberian nilai akan dipantau, dievaluasi dan ditingkatkan secara berkelanjutan.

\section{F. Proses-proses Val IT}

Proses-proses Val IT yang disarikan dari (IT Governance Institute, 2008) terdiri dari 3 (tiga) domain, yaitu:

1. Value Governance (VG)

Proses-proses dari value governanceadalah :

a) VG1.Kepastian akan penginformasi dan pelaksanaan kepemimpinan.

b) VG2. Pendefinisian dan pengimplementasian proses-proses.

c) VG3. Pendefinisian peran dan tanggung jawab.

d) VG4. Kepastian akuntabilitas yang sesuai dan yang dapat diterima.

e) VG5. Pendefinisian Kebutuhan akan Informasi

f) VG6. Penetapan Kebutuhan Pelaporan

g) VG7. Penetapan Struktur Organisasi

h) VG8. Penetapan Arah Strategi

i) VG9. Pendefinisian Kategori Investasi

j) VG10. Penentuan suatu Target Portofolio Campuran

k) VG11. Pendefinisian Kriteria Evaluasi Berdasarkan Kategori

2. Portofolio Management (PM) Proses-proses dari portofoliomanagementadalah :

a) PM 1. Pemeliharaan Sumber Daya Manusia

b) PM 2. Pengidentifikasian Kebutuhan Sumber daya

c) PM 3. Pelaksanaan Analisis Gap

d) PM 4. Pengembangan Perencanaan Sumberdaya

e) PM 5. Pemantauan Kebutuhan dan Utilisasi Sumberdaya

f) PM 6. Penetapan Anggaran Investasi

g) PM.7 Pengevaluasian Inisialisasi Konsep Program Business case

h) PM 8. Pengevaluasian dan Pemberian Suatu Skor yang Relatif Untuk Program Business case

i) PM 9. Pembuatan Pandangan Portofolio Secara Keseluruhan

j) PM 10. Pembuatan dan Pengkomunikasian Keputusan Investasi

k) PM 11. Tahapan dan Pendanaan dalam Pemilihan Program-program
1) PM 12. Optimalisasi Kinerja Portofolio

m) PM 13. Penentuan Kembali Prioritas Portofolio

n) PM 14. Pemantauan dan Pelaporan Kinerja Portofolio

3. Investment Management (IM)

Proses-proses dari investment management adalah

a) IM 1. Pengembangan Definisi Tingkat Tinggi dari Peluang Investasi

b) IM 2. Pengembangan Inisialisasi Konsep Program Business case

c) IM 3 Pengembangan Pemahaman yang Jelas dari Program Kandidat

d) IM 4. Pelaksanaan Analisis Alternatif

e) IM 5. Pengembangan Perencanaan Program

f) IM 6. Pengembangan Realisasi Perencanaan yang Menguntungkan

g) IM 7. Pengidentifikasian Biaya dan Keuntungan Siklus Hidup Secara Penuh

h) IM 8. Pengembangan Program Business case yang Terperinci

i) IM 9. Pelaksanaan Tanggung jawab

j) IM 10. Penginisialisasian, Perencanaan dan Peluncuran program

k) IM 11. Pengelolaan Program

l) IM 12. Pengelolaan/ Penelusuran Keuntungan

m) IM 13. Pembaharuan Business case

n) IM 14. Pemantauan dan Pelaporan Kinerja Program

o) IM 15. Tahap Akhir Program

\section{G. Maturity Level Val IT}

Maturity level pada Val IT dibedakan menjadi 6 (enam) tingkat skala kematangan yang sama seperti pada Cobit, yaitu (IT Governance Institute, 2008):

1. Level 0 (Non Existent)

2. Level 1 (Initial)

3. Level 2 (Repeatable)

4. Level 3 (Defined)

5. Level 4 (Managed)

6. Level 5 (Optimised

\section{METODOLOGI PENELITIAN}

Dalam penelitian ini, akan dilakukan auditing tata kelola teknologi informasi dan perencanaan investasi teknologi informasi melalui beberapa tahapan yangsebagai berikut:

a) Perencanaan, yaitu kegiatan awal sebelum penelitian yang terdiri dari menentukan lokasi audit, menyiapkan surat izin riset, meninjau lokasi audit dan enentukan jadwal audit.

b) Identifikasi permasalahan, yaitu identifikasi masalah tata kelola TI dan masalah perencanaan investasi TI.

c) Kajian literatur yang berhubungan dengan tata kelola TI dan perencanaan Investasi TI.

d) Menyiapkan kuesioner, yaitu menyiapkan kuesioner COBIT untuk domain Deliver \& 
Support yang terdiri dariDS4, DS 5 dan DS 11, kemudian menyiapkan kuesioner Val IT untuk proses Value Governance (VG), Portofolio Management (PM) dan Investment Management (IM)

e) Mengumpulkan data dan fakta melalui wawancara/interview, identifikasi TI yang digunakan, identifikasi pengelolaan TI, identifikasi perencanaan investasi TI.

f) Melakukan analisis terhadap kuesioner yang telah diisi oleh responden, kemudian menentukan maturity level COBIT dan Val IT

g) Membuat laporan lengkap

\section{Metode Pengambilan Data}

.Dalam penelitian ini, penulis telah menentukan pengambilan data dengan cara :

a. Interview/wawancara

b. Kuesioner

c. Observasi

Kematangan dan kemampuan dari setiap proses TI akan diidentifikasi. Penilaian mengacu pada model maturity level COBIT Management Guidelines menggunakan rumus :

Indeks $=$ $\sum$ (jawaban)

\section{$\sum$ (pertanyaan kuesioner)}

Dengan kriteria index penilaian :
(a) 0-0,50 Non-Existent
(b) 0,51-1,50 Initial/Ad Hoc
(c) 1,51-2,50 Repeatable But Intuitive
(d) 2,51-3,50 Define Process
(e) 3,51-4,50 Managed and Measurable
(f) 4,50-5,00 Optimised

\section{A. Pendekatan Penilaian COBIT dan VAL IT}

Dalam hal penilaian tata kelola dan perencanaan investasi TI pada PT. Candi Malindo Bangkit, dilakukan pendekatan dengan tahapan yang terdiri dari: (1)Pengidentifikasian proses-proses COBIT dan Val IT di PT. Candi Malindo Bangkit; (2) Analisis Kuesioner; (3)Mengusulkan pelaksanaan prosesproses COBIT dan Val IT yang harus dilakukan pada PT. Candi Malindo Bangkit; (4) Hasil akhirnya akan diambil keputusan yang berkaitan dengan tata kelola dan perencanaan investasi TI pada PT. Candi Malindo Bangkit.

\section{B. Identifikasi Proses-proses COBIT dan VAL IT}

Pelaksanaan analisis tata kelola TI yang ada di PT. Candi Malindo Bangkit dilakukan terlebih dahulu dengan pengidentifikasian proses-proses COBIT dan Val IT berdasarkan hasil survey kuesioner tentang ada atau tidaknya proses-proses tersebut. Pertanyaan kuesioner menjelaskan setiap proses COBIT dan Val IT yang dilakukan oleh pihak PT. Candi Malindo Bangkit berdasarkan jawaban Ya atau Tidak.dan dihitung prosentasenya. Berdasarkan prosentase jawaban Ya dan Tidak tersebut diambil kesimpulan apakah proses tersebut sudah dilakukan atau belum. Jika jawaban Ya> (lebih besar dari) $50 \%$ dinyatakan proses COBIT dan Val IT tersebut sudah dilakukan. Jika ada proses-proses yang belum dilakukan, maka akan diusulkan beberapa kegiatan yang harus dilakukan pada setiap proses. Kemudian untuk Val IT jika sudah dilakukan, juga akan diukur performanya apakah sudah sangat baik, baik, cukup, kurang baik, ragu-ragu atau tidak dapat diterapkan.

Data responden sebanyak 5 (lima) orang yang dipilih berdasarkan keterlibatan dan tingkat pengetahuan tentang TI yang terdiri dari Manajer proyek, Engineer, Staf TI dan Pengelola Data.

\section{HASIL DAN PEMBAHASAN}

\section{A. Hasil Analisis Tata kelola TI berdasarkan COBIT}

Berdasarkan hasil temuan proses-proses COBIT, yang telah dilakukan di PT Candi Malindo Bangkit dalam rangka menerapkan tata kelola teknologi informasi ditunjukkan pada tabel 1 .

Tabel 1.Maturity Level COBIT

\begin{tabular}{|c|c|c|c|}
\hline Domain & Proses & $\begin{array}{c}\text { Current } \\
\text { Maturity }\end{array}$ & $\begin{array}{l}\text { Expected } \\
\text { Maturity }\end{array}$ \\
\hline DS4 & $\begin{array}{l}\text { Menjamin } \\
\text { pelayanan } \\
\text { berkelanjutan }\end{array}$ & 1,01 & 2 \\
\hline DS5 & $\begin{array}{l}\text { Menjamin } \\
\text { keamanan } \\
\text { system }\end{array}$ & 0,88 & 2 \\
\hline DS11 & Mengelola data & 1,08 & 2 \\
\hline & & \multicolumn{2}{|c|}{$\begin{array}{l}-\square \text { Current Maturity } \\
\rightarrow-\text { Expected Maturity }\end{array}$} \\
\hline
\end{tabular}

Gambar 2.Radar Chart Maturity Level pada Domain Deliver \& Support

Dengan demikian, berdasarkan gambar 2 diatas maka dapat disimpulkan bahwa tatakelola TI khususnya dalam hal pelayanan yang berkelanjutan, keamanan sistem informasi dan manajemen data adalah masih berada pada level 1 yaitu bersifat Initial/ Ad hoc. Artinya perusahaan secara reaktif melakukan penerapan dan implementasi teknologi informasi sesuai dengan kebutuhan-kebutuhan mendadak yang 
ada, tanpa didahului dengan perencanaan sebelumnya.

\section{B. Hasil Analisis Perencanaan Investasi TI berdasarkan Val IT}

Berdasarkan hasil identifikasi proses-proses Val IT, maka dapat dihitung maturity level dengan rumus:

Indeks $=$ $\sum$ (jawaban)

$\sum$ (pertanyaan kuesioner)

Setelah melalui proses penghitungan, maka didapatkan hasil maturity level seperti ditunjukkan pada tabel 2 .

Tabel 2.Maturity level Val IT

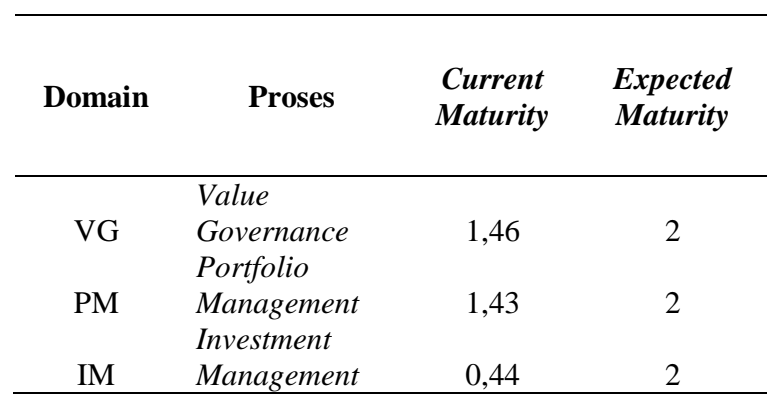

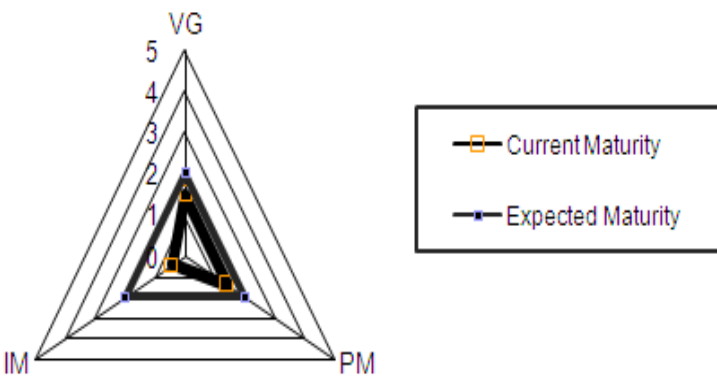

Gambar 3.Radar Chart Maturity level Val IT

Berdasarkan gambar 3 maka dapat disimpulkan bahwa PT. Candi Malindo Bangkit berada pada tingkat kematangan 1 (initial/ad hoc) pada domain Value Governance (VG) dan Portfolio Management (PM) yang artinya perusahaan telah mengenal isu atau masalah yang ada dan perlu diarahkan. Tidak ada proses standarisasi, tetapi sekurang-kurangnya ada pendekatan khusus (ad hoc) yang cenderung diterapkan pada individu-individu atau atas dasar kasus demi kasus. Pendekatan terhadap keseluruhan manajemen tidak terorganisir.

Sedangkan tingkat kematangan pada domain Investment Management (IM) masih berada pada level Non-Existent. Hal tersebut disebabkan karena proses-proses investment management pada PT. Candi Malindo Bangkit belum dikenali secara utuh.Organisasi belum mengenal adanya isu atau permasalahan yang harus diselesaikan dan masih banyak proses-proses investment management yang belum dilakukan.

\section{Usulan Perbaikan Tata Kelola TI}

Dalam hal tata kelola TI, tampak jelas bahwa keamanan sistem informasi harus menjadi prioritas utama dalam melakukan perbaikan. Namun hal itu bukan berarti tidak melakukan perbaikan pada domain yang lain.

Untuk meningkatkan keamanan sistem informasi perlu menambah perangkat keamanan TI dan membuat prosedur-prosedur keamanan yang diotentifikasi, dikontrol dan dilaporkan secara periodik.Manajemen sebaiknya mengadakan pelatihan dan sertifikasi untuk karyawan-karyawan khususnya yang berhubungan dengan tata kelola TI.Menerapkan tata kelola TI yang terintegrasi dengan investasi TI dan sesuai dengan standar internasional.

Meningkatkan tata kelola teknologi informasi pada aspek sistem maupun manajemen sesuai dengan target maturity level minimal berada pada posisi level 2 yaituRepeatabledengan harapanperusahaan telah memiliki pola yang berulangkali dilakukan dalam melakukan manajemen aktivitas terkait dengan tata kelola teknologi informasi.

Meningkatkan pelayanan TI yang berkelanjutan, manajemen data dan keamanan sistem informasi,sebaiknya lebih diprioritaskan pada keamanan sistem informasi karena keamanan sistem informasi merupakan domain terlemah sedangkan keamanan sistem informasi sangat penting untuk menjaga realibilitas, integritas dan validitas data.

Senantiasa melakukan evaluasi atau audit secara rutin dan berkala setiap tahun untuk menilai kemajuan proses tata kelola TI dan terus memperbaiki kekurangan yang ada.

\section{Usulan Perbaikan Perencanaan Investasi TI}

Dalam hal perencanaan investasi TI, Investment Management merupakan domain yang relatif terlemah diantara domain lain, jadi domain ini harus menjadi fokus perhatian manajemen sehingga hasil investasi yang dikembangkan menghasilkan keuntungan yang sesuai dengan harapan, baik itu keuntungan yang tangible maupun yang intangible. Langkah-langkah perbaikan yang dapat dilakukan antara lain perusahaan harus lebih fokus dalam memonitor dan memberi tugas atau tanggung jawab untuk mencapai keuntungan, pengendalian biaya, mengelola resiko dan mengkoordinir aktivitas seluruh proyek sehingga tidak terjadi kebingungan. Mengidentifikasi dan mendokumentasikan tanggung jawab, jadwal penyerahan, proses monitoring, form 
register. Kesemuanya harus dibuat secara detail beserta penjelasan resiko-resiko yang mengancam keberhasilan dari tiap outcome kunci dan bagaimana resiko itu akan dikurangi.

Meningkatkan perencanaan investasi teknologi informasi sesuai dengan target maturity level minimal berada pada posisi level 2 yaitu Repeatable dengan harapan prosedur telah distandarisasi, didokumentasikan dan dikomunikasikan melalui pelatihan, prosedur dikembangkan sebagai bentuk formalisasi dari praktek yang ada.

Lebih memperhatikan manajemen investasi karena investasi TI akan memberikan dampak dan manfaat pada kemajuan perusahaan dimasa yang akan datang untuk bersaing dengan perusahaan lain yang sejenis.

\section{KESIMPULAN}

Berdasarkan hasil audit pada PT. Candi Malindo Bangkit diperoleh kenyataan bahwa :

1. Dalam hal tatakelola TI, berdasarkan analisis menggunakan COBIT pada perusahaan tersebut masih kurang baik dan belum sesuai dengan target yang diharapkan, yaitu berada pada level 1 (satu) atau initial/Ad hoc yang artinya perusahaan secara reaktif melakukan penerapan dan implementasi teknologi informasi sesuai dengan kebutuhankebutuhan mendadak yang ada, tanpa didahului dengan perencanaan sebelumnya.

2. Diantara tiga domain yang dianalisis, PT Candi Malindo Bangkit relatif lebih baik dalam hal manajemen data dan pelayanan yang berkelanjutan tetapi relatif lemah dalam hal keamanan sistem informasi.

3. Dalam hal penerapan perencanaan investasi teknologi informasi, berdasarkan hasil analisis Val IT pada PT. Candi Malindo Bangkit penerapannya belum direncanakan dengan baik, masih banyak pekerjaan yang tidak sesuai prosedur serta belum sejalan dengan strategi bisnis perusahaan. Pada saat ini proses pengembangan teknologi informasi berdasarkan maturity level Val IT masih berada pada level 1 yaitu Initial/Ad hoc yang artinya PT. Candi Malindo Bangkit telah mengenal tentang perencanaan investasi TI, tetapi belum sepenuhnya berhasil dan masih perlu diarahkan. Tidak ada proses standarisasi, pendekatan terhadap manajemen belum terorganisir karena masih banyak proses-proses VAL IT yang belum dilakukan.

4. Diantara tiga domain yang dianalisis, PT. Candi Malindo Bangkit relatif lebih kuat pada domainValue Governance (VG) dan Portfolio Management (PM) tetapi relatif lemah dalam hal Investment Management (IM).
Penulis menyarankan untuk penelitian selanjutnya dapat lebih fokus lagi menganalisis domain-domain yang kritis dan menggunakan dua atau lebih framework berbeda sebagai bahan perbandingan dengan menyesuaikan pada objek penelitian. Framework yang digunakan bisa lebih variatif lagi misalnya dengan menggunakan ISO 27001,ISO 17799, SOX, Caldea, ITIL atau BSI 7799.

\section{REFERENSI}

Adikrisna, L. O. R. (2008). Analisis Tatakelola Teknologi Informasi PT. Surveyor Indonesia menggunakan Kerangka Kerja CobIT (Studi kasus: Proses DS-13 Mengelola Operasi).

IT Governance Institute. (2005). Cobtrol Objectives for Information and Related Technology (COBIT) versi 4.1. IT Governance Intitute.

IT Governance Institute. (2008). Enterprise Value: Governance of IT Investments, The Val IT Framework2.0 Extract. IT Governance Intitute.

Kadir, A., \& Terra. (2005). Pengenalan Teknologi Informasi. Yogyakarta: Andi.

Manorang, G. (2012). Audit Tata Kelola Teknologi Informasi Pada PTPN 13 Pontianak menggunakan Framework COBIT. Socioscientia, 4, 97-114.

Suharsono, T. N. (2007). Penggunaan Val IT Framework untuk menilai Perencanaan Investasi teknologi Informasi (Studi Kasus: Universitas Sangga Buana YPKP Bandung).

Witanti, W., \& Falahah. (2007). Val IT : Kerangka Kerja Evaluasi Investasi Teknologi Informasi. In Seminar Nasional Aplikasi Teknologi Informasi (pp. 31-37). Universitas Islam Indonesia Yogyakarta.

\section{PROFIL PENULIS}

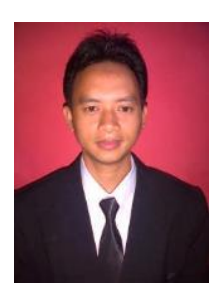

Yayan Hendrian, S.T.,M.Kom. Tahun 2009 Lulus Program Strata Satu (S1) Program Studi Teknik Elektro Universitas Tama Jagaraksa. Tahun 2012 Lulus Program Strata Dua (S2) ProgramStudi Ilmu Komputer STMIK Nusa Mandiri Jakarta. Saat ini bekerja sebagai tenaga pengajar program studi Teknik Komputer di UBSI Jakarta. 